症例

術後，難治性食道気管支㾇を併発した特発性食道破裂の 1 治験例

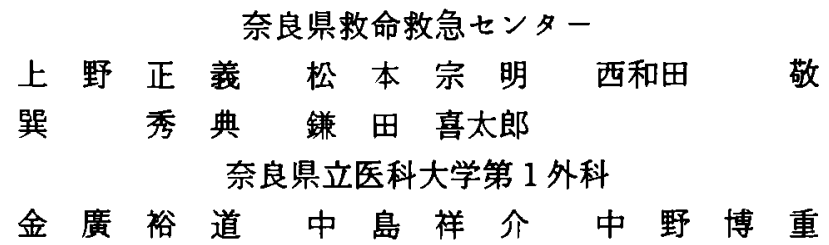

症例は34歳の男性．冝食後嘔吐し，その直後より心窩部㧍よび背部痛が出現した，近 医を受診し，汎発性腹膜炎の診断にて当センターに稆介された。精查の結果，特発性食 道破裂と診断し，発症から10時間後に左第 5 肋間より開胸した。多量の混濁した胸水と 綎隔内に食物残㚗を認めた。胸部食道下部左㑡壁に，約 $5 \mathrm{~cm}$ の縦走した破裂㓣を認め， 同部の縫合閉鎖と胸腔ドレナージ衍を施行した。術後，繾合不全を発生し，胸腔内膿場 を形成した，栄盖管理，抗生物質投与などの他，胸腔内持続洗浄を行ったか，食道気管 支瘦を併発した。ささらに, MRSA 感染症す併発したが, 保存的療法にて瘦孔は閉鎖した。 特発性食道破裂は比較的まれな疾患であるが，食道気管支瘦併発例はきわめて少ない。 本症に捣いては自験例のごとく，術後繾合不全を発生し，難治性瘦孔を併発した場合で あ，保存的療法にて俥快したことから，十分なドレナージが重要であると考えられた。

事引用語：特発性食道破裂，食道気管支虔

緒言

特発性食道破裂(以下本症)は, 1724年 Boerhaave $\mathrm{e}^{1)}$ により初めて報告され，本邦です200例以上の報告がみ られている2!.今回著者らは、特発性食道破裂術後に難 治性食道気管支瘦を併発し，保存的療法にて治虑せし めた症例を経験したので，若干の文献的考察を加えて 報告する。

\section{症 例}

症例：34歳, 男性.

主訴：心穿部および背部痛。

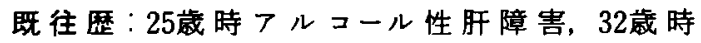
Mallory-Weiss 症候群。

家族歴：特記事項なし。

現病歴: 平成 2 年 6 月 12 日, 昼食後嘔吐し, その直 後より心蓇部および背部痛が出現した。近医を受診し， 沉発性腹膜炎の診断にて当せンターに紹介された。

入院時現症: 意識清明, 体格栄着中等度。体温 36.8 度, 呼吸数 $22 /$ 分. 眽拍 $112 /$ 分, 血圧 $120 / 70 \mathrm{mmHg}$. 眼 瞼結膜に董血なく、眼球結膜に黄染なし、胸部は打聴
診上異常なく，腹部は平担で，心骷部に筋性防御を認 めた。皮下気尰は認めなかった。

入院時検查成嚗: 末梢血液検査は正常. 血液生化学 検查にて GOT $3261 \mathrm{IU} / l$, GPT $140 \mathrm{IU} / l$, LDH 7701U/ $l$ および $\gamma$-GTP $870 \mathrm{IU} / l$ と肝機能異常を認めた。 た，動脈血ガス分析にて軽度の低酸素血症を認めた。

胸部 X 線所見：来院時には特に異常を認めなかっ た（図 1 -左）。呼吸困難が出現してきたため，来院 7 時間後に再度, 胸部 X 線撮影を行ったところ, 少量の 緃隔気腫と左胸水の眝留を認めた（図 1-右）.

胸部単純 CT 所見：来院 7 時間後に撮影した緹隔条 件の CT 像では, 秤隔気腫, 左胸水貯留. 䋎隔内異物 と思われる腫瘤様陰影および左下葉の浸潤陰影を認め た (図 2 -上). 同部の肺野条件では, 緃隔気尰, 左下 葉の浸潤陰影がより明瞙に認められた（図 2-下).

以上より，特発性食道破裂と診断し，発症から10時 間後に緊急手術を施行した。

手術所見：左第 5 肋間より開胸した。多量の涅濁し た胸水と緥隔内に食物残㚗の貯留を認め，胸部食道下 部左側壁に約 $5 \mathrm{~cm}$ の絽走する破裂創を認めた。破裂創 の炎症が軽度であったため, 同部を一期的に梿合閉鎖 


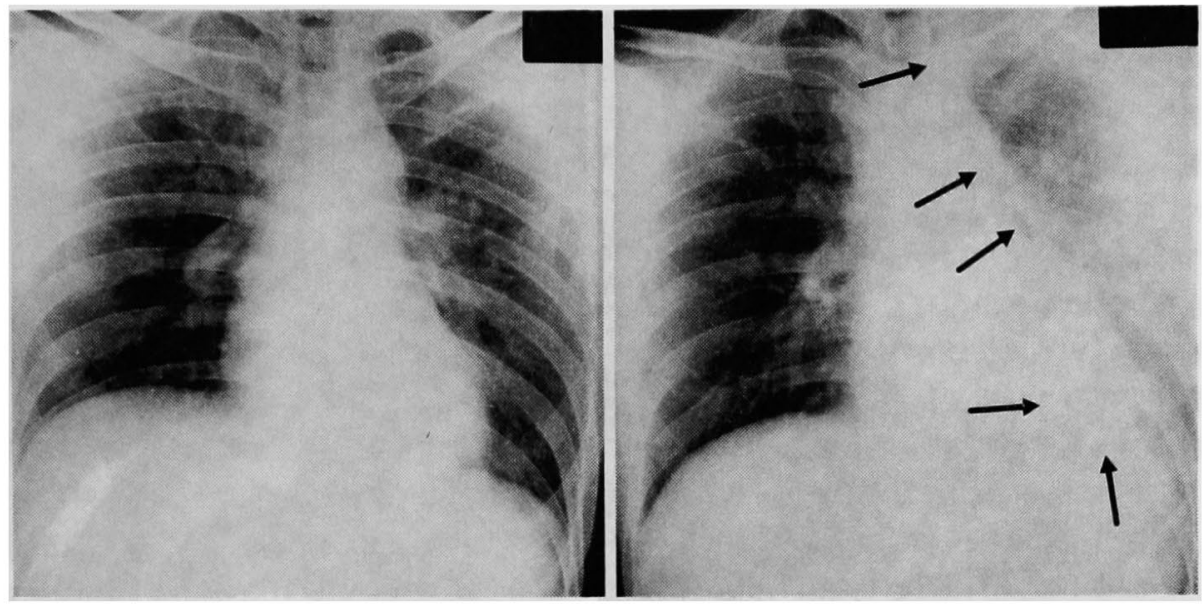

図 1 胸部単純 $\mathbf{X}$ 線像：来院時には特に異常を認めなかった（左）. 来院 7 時間後に は, 少量の縦隔気腫（矢印）と左胸水の眝留を認めた（右）.
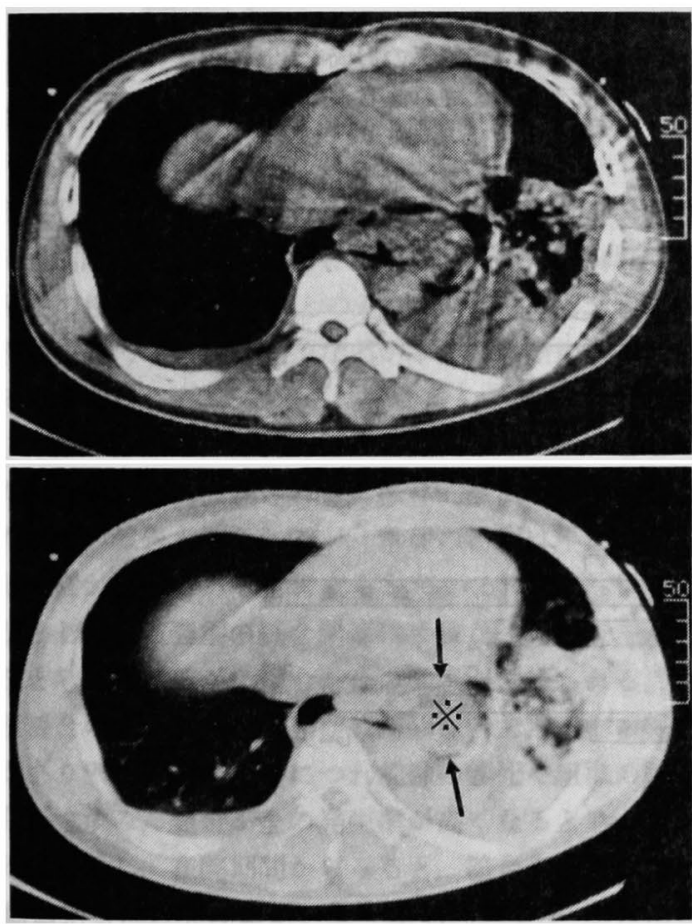

图 2 胸部単純 CT 像：綎隔気腫 (矢印)および綎隔内

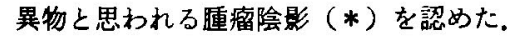

し胸腔内に 2 本, 縫合部綎隔内に 1 本のドレナージを 留置した。

術後経過：術後第 3 病日に䋖合部絽隔内トレーンよ り朖汁が排泄された，第 9 病日に食道透視を行ったと ころ, 造影剂の漏出および胸腔内膿湯の形成を認めた
(図3-左). 破裂創の栈合不全, 胸腔内膿瘍と診断した。 抗生物質・第13因子製剂の投与，高カロリー輸液扎よ び小腸瘦を造設し経腸栄盖を行った。また，唾液分泌 抑制のため硫酸てトロピンの投与を行った。さらに, ドレーンよりの持続洗净を行ったところ，高熱は消失 した。しかし，第37病日に施行した瘦孔造影にて，食 道および気管支が造影され，食道気管支瘦の併発を認 めた(図 3-右).さらに, MRSA 感染を併発したため, 持続洗浄を行らとともに塩酸ハンコマイシンの経口投 与を行った。第49病日に施行した食道透視にて，破裂 創の閉鎖を確認したため，第54病日より経口摄取を開 始した，以上の治療にて癭孔は徐々に縮小し，第67病 日に施行した瘦孔造影にて瘦孔の閉鎖を確認した。第 79病日に軽快退院した。 以上の経過を図 4 に示した。

\section{考察}

本症は，1724年 Boerhaave"により初めて報告され た疾患であり，外傷，巽物，医原性などの外的要因や 腫瘍，潰瘍，炎症などの器質的基礎疾患なしに食道壁 全層が突発的に破裂する疾患である。本邦においては， 1934年吉田 ${ }^{3)}$ により最初に報告されて以来, 現在まで に200例以上の報告がみられる2)，性別では男性が90\% 以上と，圧倒的多数を占め，年路では30歳から50歳代 が全体の70\%以上を占めている2!. 自験例む34歳の若 年男性であった，破裂創は縦走するものがはとんどで， 胸部食道下部左側壁に好発する。この理由として，同 部の部分的あるいは病的脆弱性, さらに外周支持組織 の欠如などの関与が考えられている2)，発症の誘因は 领酒後の嘔吐が多く，嘔吐により食道内圧の急激な上 

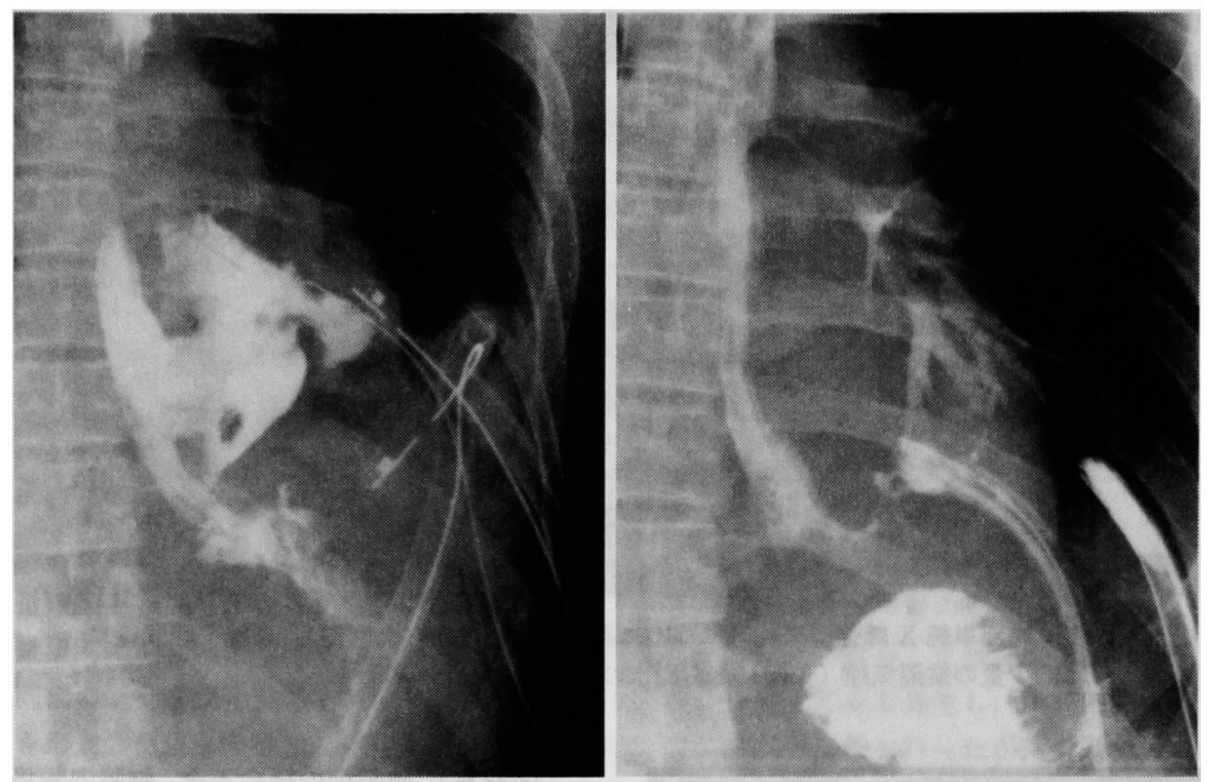

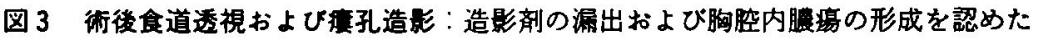
(左)，胸腔ドレーンより造影すると，食道および気管支が造影され，食道気管支膺 の合併が認められた（右）.

('C)

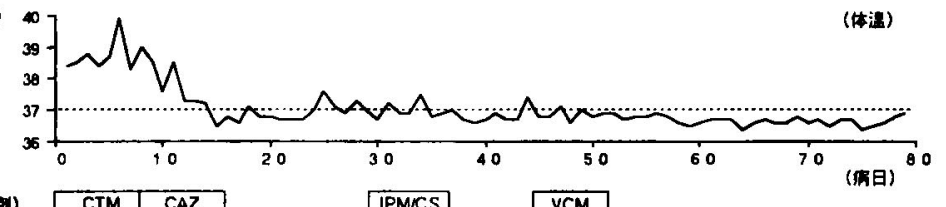

(沂生衫)

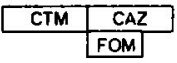

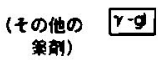

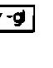

(난두)

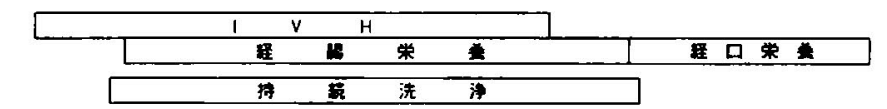

(

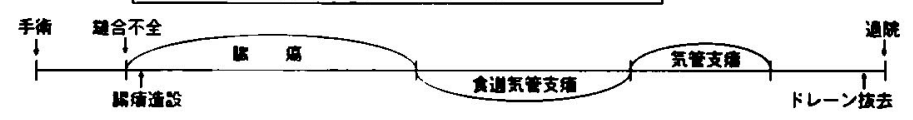

図 4 術後释過
昇, 食道と胃の協調運動の失調を来たすため, 解剖学 的に抵抗性の减弱する部位に破裂がが起こるとされて いる゙，自験例す嘔吐後に発症し, 胸部食道下部左側壁 に約 $5 \mathrm{~cm}$ の走した破裂飤がみられた。

初発症状は, 嘔吐直後から数時間以内に起こる上腹 部痛，呼吸困難および背部痛が多いが，嘔吐などの特 別な誘因なく発症する症例すみられる2). Mackler ${ }^{5)}$ は，嘔吐，下胸部痛および頸部皮下気腫を 3 徵として いるか，実際に皮下気尰を認める症例は少ないとされ
ている4. 大多数の症例で発症後数時間以内に医療機 関を受診しているが，初診時に本症と診断されるのは 約30\%であり，24時間以内の診断率す50\%以下に過ぎ ず，また，胃・十二指腸潰瘍穿孔，急性脺炎などの急 性腹症, 心筋梗塞, 胸部大動脈瘤などと誤診されるこ ともあると報告されている2．自験例においても，嘔吐 直後に心窝部および背部痛にて発症し，縦隔気腫は認 められたが，皮下気腫は認められなかった。ささらに， 他院にて沉発性腹膜炎と診断されており，本症の特徽 
と合致していた。

本症の診断に関しては，胸部単純 X 線上の綎隔拈よ び频部の気腫像が重要である。限局性縦隔気腫である Naclerio")の V-sign が本症のX 線所見として有用と されているが，実際に認められることは少なく”，むし ろ水気胸を伴うことが多いとの報告がみられる2，水 気胸の存在が早期に診断する上で意義があると思われ るが，明らかに認められるまでには24時間以上の経過 を要する場合が多く2，自験例のごとく，初診時の胸部 $\mathrm{X}$ 線所見に情報が得られない場合もあり，病状に応じ た経時的な X 線検查が必要と考えられる.水容性造影 剂を用いた食道造影により，造影剂の綐隔内および胸 腔内への漏出を証明すれば訩断は容易であるが，偽陰 生例存在し注意が必要である ${ }^{48)}$. 胸部 CT 検查は胸 部知患の診断において非常に有用であり，激しい胸痛 で嘔吐を繰り返す症例，あるいは全身状態が不良の症 例に対しても施行でき，本症においてもその有用性が 重視されている9．激しい嘔吐などの本症の特徽的な 症状を欠く場合，特に，解離性大動脈留との鑑別に有 用であるとの報告るみられる ${ }^{10)}$ ．自験例においても胸 部 CT 倹查にて，稆隔気腫および絽隔内異物と思われ る畽瘤陰影を認め，本症之診断した，他に，胸腔穿刺 液中の性状から消化管との連絡を薙 らこと²，食道内 梘鏡検査"，色素の敛用”などが本症の診断に有用であ ると考えられる。

本症の治療は，外科的療法と開胸ドレナージを含め た保存的療法に大別される．保存的療法のみで治㽶し た症例の報告もみられるが，本症の治療は早期の外科 的処置が重要であると考えられている2148). 外科的療 法として，破裂創の䋃合閉鎖は手技が容易で有用な方 法と考えられるが，䋖合不全の発生が危惧される，直 接释合の安全限界は，発症12時間以内であるとの報告

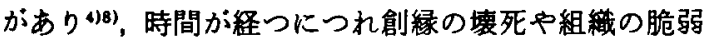
化がすすみ，梿合不全の発生率が高くなると考光られ る.しかし，在院期間からみると，梿合不全が発生し た場合です保存的療法の場合と同様であり，䋖合不全 がなければ在院期間は半减するとの報告がみられ $ろ^{22}$.この点からも，全身状態が許せば積極的に手術療 法を行らべきであると考えられる。また，縫合不全対 策として， fundic patch 法，有蒌横隔膜弁法など種々 な工夫がなされている゙11.

自験例においては，発症10時間後に緊急手術を施行 したにもかかわらず，術後縫合不全を発生し，胸腔内 朖湯および食道気管支瘘を併発した，著者らの検索し
た。本症の本邦報告例の範囲内では，食道気管支瘦併 発例は自検例を含め，4例のみであった 管支瘦は非常にまれな併発症であり，その治療に難汥 し，瘦孔の原因と考光られた異物除去術を行った症 例 ${ }^{12)}$ 、フィブリン糊製郕を瘦孔内に注入した症例(13)，瘦 孔閉鎖および肺葉切除術を施行した症例(4)が報告され ている．脺液瘦および消化管瘦などの難治性瘦孔に対

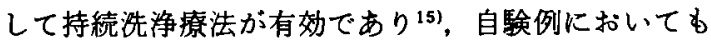
高カロリー輸液，経腸栄着および抗生成投与などの一 般的治療法と胸腔内持続洗浄療法にて治痖させること ができた。

自験例のごとく，棅逢合不全を生じ膿胸，食道気管支 瘦を併発した症例においても，保存的療法にて治撚す る症例もみられ，十分なドレナージが肝要であると考 えられた。

\section{結語}

特発性食道破裂術後に難治性食道気管支瘦を併発 し，保存的療法にて治䈍せしめた症例を報告し，若干 の文献的考察を加えた。

\section{文献}

1) Boerhaave $\mathrm{H}$ : Atrocis, nec descripti prius, morbi historia. Secundum medicae artis leges conscripta. Lugduni Batavorum Bountesteniana. 1724, Derbes VJ, Mitchell RE (trans). Bull Med Libr Ass 43 : 217-240, 1955

2）貴島政邑：いわ妕る特発性食道破裂の病態と治 療。臨外 $42: 335-341,1987$

3）吉田太助：偶発性食道破裂の 1 例。海軍軍医会誌 $24: 97,1935$

4) Abott OA, Mansour KA, Logan WD, et al: Atraumati so-colled "spontaneous" rupture of esophagus, a review of 47 personal cases with comments on new method of surgical therapy. $J$ Thorac Cardiovasc Surg $59: 67-83,1970$

5) Mackler SA: Spontaneous rupture of the esophagus: An experimental and clinical study. Surg Gynecol Obstet 95 : 345-356, 1952

6) Naclerio SA: The V-sign in the diagnosis of spontaneous rupture of the esophagus (an early roentgen clue). Am J Surg $98: 291-298,1957$

7）市川英幸, 大倉充久, 䒜原迪彦他：特発性食道破裂 の 2 治験例一本邦112例の統計的観察一。外科治療 $47: 383-392,1982$

8) Curci JJ, Horman MJ : Boerhaave's syndrome, The importance of early diagnosis and treat- 
ment. Ann Surg 183: 401-408, 1976

9）竹田明彦, 唐司則之, 紙津照雄他：特発性食道破裂 の 1 治験例. 日踄外医会誌 $48: 220-225,1987$

10) Jaworski $A$, Fischer R, Lippmann $M$ : Boerhaave's syndmore, computed tomographic findings and diagnostic considerations. Arch Intern Med 148 : 223-224, 1988

11）小泉澄彦, 洲之内広紀, 吉見富洋他：特発性食道破 裂の治療。手術 $21: 397-404,1987$

12）加古 健，湯川孝雄，梅田哲正他：朖胸，気管支藻 を合併した特発性食道破烈の 1 治鈳例. 胸部外科
$39:$ 905-908, 1986

13）山川 真, 三浦 稫, 川瀬恭平他：術後難治性漠孔 に対してフィプリン糊製戍が有奻であった特発性 食道破裂の 1 例。日臨外医会誌 $51 ： 104-110$ ， 1990

14）高松英夫，秋山 洋，野口啓幸他：特発性食道破裂 治密後の胃食道逆流現象が原因と思われる食道気 管支漊の 1 例. 小肾外科 $23: 353-357,1991$

15）記井英治, 山口真彦，林 七菜他：難治性瘦孔に対 する持続洗浄㞠法。外科 49:1549-1552, 1987

\title{
A CASE OF SPONTANEOUS RUPTURE OF THE ESOPHAGUS WITH REFRACTORY ESOPHAGO-BRONCHIAL FISTULA
}

\author{
Masayoshi UENO, Muneaki MATSUMOTO, Takashi NISHIWADA, Hidenori TATSUMI, \\ Kitarou KAMATA, Hiromichi KANEHIRO*, Yoshiyuki NAKAJIMA* \\ and Hiroshige NAKANO* \\ Nara Emergency and Critical Medical Center \\ *First Department of Surgery, Nara Medical University
}

A 34-year-old man visited a nearby hospital because of epigastralgia and dorsalgia following vomiting after lunch. Panperitonitis due to unknown origin was suspected, and then he was sent to the emergency and critical medical center. Since spontaneous rupture of the esophagus was diagnosed with minute examination, an emergency left anterolateral thoracotomy was selected through the 5th intercostal space about 10 hours after the onset. A large amount of turbid pleural effusion in the thoracic cavity, and a large quantity of food particles in the mediastinal space were observed. As a longitudinal tear, about $5 \mathrm{~cm}$ long, was revealed in the left wall of the lower esophagus, a simple esophageal suture and thoracic drainages were performed. After the operation suture insufficiency occurred, and then an abscess was complicated in the thoracic cavity. In spite of continuous thoracic irrigation with hyperalimentation and antibiotics administration, esophago-bronchial fistula with MRSA infection developed. With these conservative therapy, the refractory fistula could be successfully closed. Spontaneous rupture of the esophagus with esophago-bronchial fistula is very rare. Even though suture insufficiency occurs and refractory fistula develops, it can be healed with conservative therapy like this case. The importance of performing the adequate thoracic drainage should be emphasized for this disease. 